\title{
Efektivitas Model Pembelajaran Kooperatif Tipe Group Investigation Terhadap Peningkatan Keterampilan Proses Sains Siswa Pada Materi Elastisitas Bahan
}

\author{
Yunita*, Yanti Sofi Makiyah \\ Pendidikan Fisika, Universitas Siliwangi \\ *Email: yunitauni217@gmail.com
}

\author{
Received: 5 Mei 2021; $\quad$ Accepted: 24 Agustus 2021; Published: 22 Oktober 2021 \\ DOI: http://dx.doi.org/10.29303/jpft.v7i2.2640
}

\begin{abstract}
The purpose of this study was to determine the effectiveness of the group investigation type cooperative learning model in improving the science process skills of high school students in material elasticity. The research method used was quasi-experimental and the population used was class XI MIPA one of the public high schools in Tasikmalaya district and the sample used was class XI MIPA 4. The results of this study obtained an effect size value of 3.91 and categorized as high. The t-test of science process skills in students obtained $t_{\text {count }}$ of 26.39 and $t_{\text {table }}$ of 2.86 because $t_{\text {count }}>t_{\text {table }}$ then Ho was rejected and Ha was accepted. Thus, it can be concluded that the group investigation type cooperative learning model was effective in improving the science process skills of high school students on the elasticity of the material.
\end{abstract}

Keywords: Group Investigation; Science Process Skill; Material Elasticity

\section{PENDAHULUAN}

Dalam proses pembelajaran, siswa selalu diarahkan dan dituntut untuk bisa memahami materi pembelajaran dengan sebaik-baiknya, sehingga dapat mencapai tujuan pembelajaran. Namun, pada kenyatannya ketika berlangsungnya proses pembelajaran siswa tidak selalu menyerap dan memahami informasi yang telah disampaikan dengan sepenuhnya, karena jika sudah terlalu lama belajar, maka siswa akan menjadi tidak fokus dan berkonsentrasi. Terlebih lagi pada mata pelajaran Fisika yang memuat banyak konsep ilmiah dan dianggap sebagai mata pelajaran yang menakutkan bagi sebagian siswa.

Pada era revolusi industri 4.0, diharuskan bahwa sumber daya manusia memiliki keseimbangan dalam hal teori dan praktik. Salah satu keterampilan yang dapat dimiliki saat ini yaitu keterampilan proses sains. Keterampilan proses sains merupakan seperangkat keterampilan yang digunakan para ilmuwan dalam melakukan penyelidikan ilmiah (Rustaman et al. 2010).

Menurut (Karamustafaoğlu, 2011), keterampilan proses sains terdiri dari keterampilan proses sains dasar dan terintegrasi. Keterampilan proses sains dasar terdiri dari keterampilan mengobservasi, mengklasifikasi, mengukur, dan memprediksi. Sementara itu, keterampilan proses sains terintegrasi terdiri dari keterampilan mengidentifikasi dan mendefinisikan variabel, mengumpulkan dan mengolah data, membuat tabel dan grafik, mendeskripsikan hubungan antara variabel, menginterpretasi data, merancang bahan-bahan, mengambil data, memfosmulasikan hipotesis, merancang penyelidikan, dan menarik kesimpulan.

Oleh karena itu, pada pembelajaran di sekolah khususnya pembelajaran fisika, sebagai seorang guru dituntut untuk menciptakan suasana belajar yang menyenangkan dan salah satunya yang dapat meningkatkan keterampilan siswa sesuai dengan tuntutan era revolusi industry 4.0, 
sehingga siswa dapat beradaptasi dengan kemajuan zaman. Salah satu cara yang dapat dilakukan yaitu dengan menggunakan model, metode, strategi pembelajaran yang dapat meningkatkan keterampilan siswa.

Salah satu model pembelajaran yang dapat digunakan yaitu model pembelajaran kooperatif tipe group investigation. Peserta didik belajar dalam kelompok-kelompok kecil yang heterogen, belajar bersama, saling membantu, dan melakukan investigasi untuk menemukan dan menyelesakan masalah (Irwan \& Sani, 2015)

Slavin (1996) menjelaskan bahwa model pembelajaran kooperatif tipe investigasi kelompok memiliki enam langkah pembelajaran, yaitu: (1) grouping (menetapkan jumlah anggota kelompok, menentukan sumber, memilih topik, merumuskan permasalahan), (2) planning (menetapkan apa yang akan dipelajari, bagaimana mempelajari, siapa melakukan apa, apa tujuannya), (3) investigation (saling tukar informasi dan ide, berdiskusi, klarifikasi, mengumpulkan informasi, menganalisis data, membuat inferensi), (4) organizing (anggota kelompok menulis laporan, merencanakan presentasi laporan, penentuan penyaji, moderator, dan notulis), (5) presenting (salah satu kelompok menyajikan, kelompok lain mengamati, mengevaluasi, mengklarifikasi, mengajukan pertanyaan atau tanggapan), dan (6) evaluating (masing-masing siswa melakukan koreksi terhadap laporan masing-masing berdasarkan hasil diskusi kelas, siswa dan guru berkolaborasi mengevaluasi pembelajaran yang dilakukan, melakukan penilaian hasil belajar yang difokuskan pada pencapaian pemahaman.

\section{METODE PENELITIAN}

Pada penelitian ini jika dilihat dari teknik yang digunakan adalah quasi eksperimen, dimana penelitian quasi eksperimen digunakan untuk mengetahui pengaruh dari suatu percobaan atau suatu perlakuan terhadap subjek yang ditentukan oleh peneliti. Penelitian ini dilakukan di salah satu SMA Negeri di kabupaten Tasikmalaya. Dalam penelitian ini populasi yang digunakan adalah siswa kelas XI salah satu SMA Negeri di kabupaten Tasikmalaya yang berjumlah 5 kelas. Penentuan populasi dilakukan secara sengaja atau purposive. Sampel dalam penelitian ini adalah kelas XI MIPA 4. Penentuan sampel penelitian dilakukan dengan teknik purposive sampling dimana penentuan sampel dengan pertimbangan tertentu.

\section{HASIL DAN PEMBAHASAN Hasil}

Untuk mengetahui efektivitas dari penggunaan model pembelajaran kooperatif tipe group investigation terhadap peningkatan keterampilan proses sains siswa, maka dilakukan pretest dan posttest dengan memberikan soal-soal evaluasi untuk mengukur peningkatan keterampilan proses sains siswa. Berdasarkan hasil pretest dan posttest dapat disimpulkan bahwa penggunaan model pembelajaran kooperatif tipe group investigation memiliki efek terhadap peningkatan keterampilan proses sains siswa. Hal ini berdasarkan peningkatan nilai effect size dan juga dapat dilihat pada hasil uji-t. hasil uji nilai effect size dapat dilihat pada tabel 1 berikut.

Tabel 1. Nilai effect size keterampilan proses sains

\begin{tabular}{cccccc}
\hline $\begin{array}{c}\text { Rata-rata } \\
\text { Pretest }\end{array}$ & $\begin{array}{c}\text { Rata-rata } \\
\text { Posttest }\end{array}$ & $\begin{array}{c}\text { Simpangan } \\
\text { Standar Pretest }\end{array}$ & $\begin{array}{c}\text { Simpangan } \\
\text { Standar Posttest }\end{array}$ & Effect Size & $\begin{array}{c}\text { Kriteria Effect } \\
\text { Size }\end{array}$ \\
\hline 34.00 & 74.50 & 8.83 & 8.26 & 3.91 & Sangat Besar \\
\hline
\end{tabular}


Uji hipotesis dilakukan untuk melihat ada dan tidaknya perbedaan tingkat keterampilan proses sains pada siswa setelah diberi perlakuan antara pretest dan posttest. Hasil uji hipotesis dapat dilihat pada tabel 2.

Tabel 2. Uji Hipotesis Keterampilan Proses Sains Siswa

\begin{tabular}{rrrrrc}
\hline rata-rata $(\mathrm{X})$ & rata-rata $(\mathrm{Y})$ & $\mathrm{SD}(\mathrm{X})$ & $\mathrm{SD}(\mathrm{Y})$ & $\mathrm{t}$ hitung & $\mathrm{t}$ tabel \\
\hline 34 & 74.5 & 8.83 & 8.26 & 26.39 & 2.86 \\
\hline
\end{tabular}

\section{Pembahasan}

Pembelajaran akan mencapai tujuan sesuai yang diharapkan ketika faktorfaktornya saling mempengaruhi. Faktor seperti lingkungan belajar, pelajar, pengajar, dan sumber belajar. Jika faktor-faktor tersebut saling mempengaruhi maka akan mencapai tujuan pembelajaran. Dalam proses pembelajaran peran guru sangat penting, dimana guru dapat berperan sebagai sumber belajar, guru yang menyediakan media pembelajaran dan guru juga dapat sebagai pencipta suasana belajar. Namun semua peran guru tidak akan berjalan jika tidak ada keterlibatan dari siswa. Salah satu cara untuk membuat siswa terlibat secara langsung yaitu dengan mengajak siswa mencari sendiri penyelesaian dari permasalahan yang ada. Model pembelajaran kooperatif tipe group Investigation dapat membuat siswa terlibat langsung dalam memecahkan permasalahannya. Sehingga dapat meningkatkan keterampilan proses sains pada siswa.

Dari data hasil penelitian yang diperoleh dapat diketahui bahwa model pembelajaran kooperatif tipe group Investigation dinilai efektif dalam meningkatkan keterampilan proses sains pada siswa. Dari rata-rata effect size dapat diketahui bahwa peningkatan keterampilan proses sains pada siswa dapat dikategorikan sangat tinggi. Berdasarkan uji-t juga dapat diketahui bahwa terdapat peningkatan keterampilan proses sains siswa.
Berdasarkan uji effect size didapatakan bahwa nilai effect size yaitu sebesar 3,91 dan dikategorikan sangat besar. Kemudian berdasarkan uji-t yang dianalisis dari data hasil pretest dan posttest diperoleh thitung sebesar 26,39 dan $t_{\text {tabel }}$ dengan taraf signifikasi 0,005 di peroleh nilai tabel sebesar 2,86 Maka menghasilkan bahwa $t_{\text {hitung }}>t_{\text {tabel, }}$ maka Ho ditolah dan Ha diterima. Hal ini menunjukkan bahwa terdapat peningkatan keterampilan proses sains siswa setelah menggunakan model pembelajaran kooperatif tipe group Investigation.

Berdasarkan hasil penelitian yang telah dilakukan, bahwa proses pembelajaran fisika materi elastisitas bahan dengan menggunakan model pembelajaran kooperatif tipe group Investigation dapat membuat siswa terlibat secara langsung dalam pembelajaran dengan cara siswa dapat berdiskusi langsung dengan temannya dan dapat menemukan sendiri pengetahuan mengenai materi elastisitas bahan dari berbagai sumber baik itu dari buku ataupun internet. Oleh karena itu, dengan menggunakan model pembelajaran kooperatif tipe group investigation, dapat merangsang keterampilan proses sains siswa karena aspek dasar keterampilan proses sains siswa berhubungan dengan langkahlangkah model pembelajaran kooperatif tipe group Investigation.

Berdasarkan nilai effect size dan uji-t, dapat disimpulkan bahwa model pembelajaran kooperatif tipe group investigation efektif dalam meningkatkan keterampilan proses sains siswa. 
Peningkatan ini tejadi disebabkan karena siswa dapat mencari sendiri penyelesaian dari permasalahan-permasalahan yang perlu diinvestigasi, dimana permasalahan itu berkaitan dengan soal-soal keterampilan proses sains.

Hasil penelitian ini sesuai dengan hasil penelitan terdahulu bahwa model pembelajaran group investigation dapat meningkatkan keterampilan proses sains pada materi koloid di SMA (Ulfah et al., 2014). Terdapat perbedaan keterampilan proses sains antara siswa yang belajar dengan model pembelajaran kooperatif tipe group investigation dengan siswa yang menggunakan model pembelajaran konvensional (Wiratana et al., 2013).

\section{PENUTUP}

Berdasarkan hasil penelitian, diperoleh bahwa didapatkan nilai effect size sebesar 3,91 dan dikategorikan tinggi. Uji-t keterampilan proses sains pada siswa diperoleh diperoleh thitung sebesar 26,39 dan $t_{\text {tabel }}$ sebesar 2,86 karena $t_{\text {hitung }}>t_{\text {tabel }}$ maka Ho ditolak dan $\mathrm{Ha}$ diterima. Dengan demikian dapat disimpulkan bahwa model pembelajaran kooperatif tipe group investigation efektif dalam meningkatkan keterampilan proses sains siswa SMA materi elastisitas bahan

\section{UCAPAN TERIMAKASIH}

Ucapan terimakasih kepada dosen pembimbing Dr. Nana dan ibu Yanti Sofi Makiyah, M.pd yang telah membimbing dalam penyusunan artikel ini. Kepada siswa SMA kela XI MIPA 4 yang bersedia meluangkan waktunya untuk melakukan penelitian ini. Kepada teman-teman seperjuangan yang telah menyemangati.

\section{REFERENSI}

Irwan, N., \& Sani, R. A. (2015). Efek Model Pembelajaran Kooperatif Tipe Group
Investigation Dan Teamwork Skills Terhadap Hasil Belajar Fisika. Jurnal Fisika, 4(1). https://doi.org/10.22611/jpf.v4i1.2567

Karamustafaoğlu, S. (2011). Improving the Science Process Skills Ability of Science Student Teachers Using I Diagrams. International Journal of Physics \& Chemistry Education, 3(1), 26-38. https://doi.org/10.51724/ijpce.v3i1.99

Slavin, R. E. (1996). Research on cooperative learning and achievement: What we know, what we need to know. Contemporary Educational Psychology, 21(1), 43-69. https://doi.org/10.1006/ceps.1996.000 4

Ulfah, A., Sahputra, R., \& Rasmawan, R. (2014). Pengaruh Model Pembelajaran Group Investigation Terhadap Keterampilan Proses Sains Pada Materi Koloid Di SMA. Program Studi Pendidikan Kimia Fkip Untan, 3-6.

Wiratana, I. K., Sadia, I. W., \& Suma, K. (2013). Pengaruh Model Pembelajaran Kooperatif Tipe Investigasi Kelompok (Group Investigation) Terhadap Keterampilan Proses Dan Hasil Belajar Sains Siswa Smp. E-Journal Program Pascasarjana Universitas Pendidikan Ganesha Program Studi IPA, 3(2), 112. 